\title{
Quantitative development and structure of zoobenthos in channels on the left margin of the Selenga River delta
}

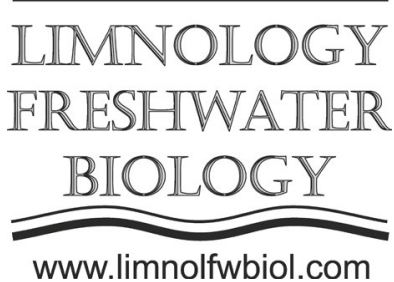

\author{
Matafonov P.V. ${ }^{1 *}$, Matafonov D.V. ${ }^{2 * *}$ \\ ${ }^{1}$ Institute of Natural Resources, Ecology and Cryology, Siberian Branch of the Russian Academy of Sciences, Nedorezova Str., 16a, \\ Chita, 672014, Russia \\ ${ }^{2}$ Russian Federal Research Institute of Fisheries and Oceanography, Baikal Branch, Khakhalova, 4b, Ulan-Ude, 670034, Russia
}

\begin{abstract}
There are only a few studies on zoobenthos in the delta of the Selenga River located at the junction of Lake Baikal and its largest tributary. The present work provides the results of research on zoobenthos in the southern (left) Selenga delta channels in 2002. Baikal amphipods and bivalves are widespread up to the upper delta. The direction and velocity of the water flow in the delta induced change of a river zoobenthos complex for a limnophilous one. Baikal amphipods are responsible for high quantitative indicators of zoobenthos in the southern channels of the delta. Low parameters of quantitative development of zoobenthos were registered during summertime. Organic matter from the catchment area of the Selenga River provides trophic resources for zoobenthos. Amphipods, bivalves and oligochaetes are involved in the transformations of suspended, sedimented and buried fractions of allochthonous matter. The authors obtained evidence on maintenance of the principal properties of the delta ecosystem as an ecotone at the time of research.
\end{abstract}

Keywords: Selenga delta, zoobenthos, Baikal endemics, quantitative development, ecotone, allochthonous matter

\section{Introduction}

Selenga River with its drainage basin as a major tributary of Lake Baikal is an object of special concern of researchers (Ecosystems..., 2005). The Selenga River delta is located at the junction of the river and Lake Baikal. Over $50 \%$ of its water and suspended matter runoff is carried by the river flow into Lake Baikal, therefore estimation of matter and energy balance as well as drivers of their physical, chemical and hydrobiological changes within the delta ecosystem with the focus on the trophic chains is considered one of the most important trends in research of the delta ecosystem (Tulokhonov, 2008). Moreover, further monitoring of the river delta ecosystem based on relevant previous studies is required for a projected regulation of the Selenga River discharge.

The delta ecosystem has obvious distinctions from the main Selenga River channel in several parameters (Sorokovikova et al., 2000; 2005; Khazheeva et al., 2005). A significant portion of biogenic elements present in the Selenga waters is involved in a biotic turnover with a contribution of the plankton communities (Sorokovikova et al., 2005). Compared to well studied on the Selenga avandelta and adjacent shallows, as well as the main Selenga riverbed (Vershinin, 1964; Bekman, 1971; Syroezhkina, 1973; Bazova, 2004; Bazova and Bazov, 2006), the data published on zoobenthos of the Selenga River delta are rare. Information on the state of zoobenthos prior to intense industrial activities in the catchment area (Vershinin, 1964; Syroezhkina, 1973; Sorokina, 1975) gives us a very general idea. Problems of the delta ecosystem and its zoobenthos became a matter of special concern during 2002-2003 research surveys (The Selenga river delta..., 2008). At that time, studies were carried out with the participation of INREC SB RAS. In 2011, Institute of General and Experimental Biology (IGEB) SB RAS undertook investigations of gammarid populations (Matafonov and Bazova, 2014). Researchers from the Limnological Institute (LIN) SB RAS studied zoobenthos in some channels of the delta under unstable hydrological conditions in 2012 (Rozhkova et al., 2016).

We suggest that the initial stage of investigating matter exchanges between Selenga and Baikal, and the role of aquatic biota in their transformations should include collection of data on zoobenthos from the main delta channels. The bulk of the water runoff and matter flow passes through the channels of the left (southern) delta margin. The authors' publications (Matafonov and

\footnotetext{
*Corresponding author. E-mail address: benthos@yandex.ru (P.V. Matafonov)

**Matafonov D.V. was the researcher of the INREC during the research of the

Selenga River delta
}

Received: December 21, 2021; Accepted: December 23, 2021; Available online: December 30, 2021
(C) Author(s) 2021. This work is distributed under the Creative Commons AttributionNonCommercial 4.0 International License. 
Matafonov, 2008; Matafonov, 2014; Matafonov et al., 2018) provide only a partial view of the zoobenthos in the southern channels in 2002-2003 and are insufficient to describe it during this period.

The present work is aimed at elucidating the quantitative development and structure of zoobenthos from the channels in the left part of the Selenga river delta.

\section{Materials and methods}

Methodologically this study is based on a structural and functional approach to investigation of aquatic ecosystems (Alimov, 2000). For this study zoobenthos samples were collected during complex studies of the ecosystem of the entire delta from March until October 2002 at the part of the Selenga River from Kabansk settlement up to the mouth of the channels on the left side of the delta: Kharauz, Galatuy, Levoberezhnaya and Shamanka (Fig.1). Totally, collected 26 samples, taking up to 3 zoobenthos samples from each site by means of a Petersen grab (sample area $0.025 \mathrm{~m}^{2}$ ). Samples were washed through a mill sieve (mesh size $0.3 \mathrm{~mm}$ ) and fixed in $4 \%$ formalin. Standard error is given for mean values.

\section{Results}

A characteristic component of communities in the main stream of the Selenga River are mayflies (Vershinin, 1964; Syroezhkina, 1973; Bazova, 2004), their highest species richness was observed at the river part near Kabansk settlement. We registered Ephemera orientalis (McLachlan, 1875), Baetis sp., Isonychia ussurica (Baykova, 1970), Heptagenia flava (Rostock, 1878) and Rhithrogena sp. Species of a rheophilic Heptageniidae family were most abundant. The Selenga River looks like a typical piedmont river in this place and the biotopes are represented by gravelpebble grounds with algal fouling. The mayflies are a particularly rare and sparse constituent in this location represented by Caenis sp., H.a flava and Potamanthus luteus (L., 1767). The first species is found everywhere in the delta: in streams Galatuy and Kharauz, for instance, in the lake system of the delta and in the Selenga River near Murzino settlement. The abundance of Caenis sp. reached 120 ind. $/ \mathrm{m}^{2}$ in the channels. Generally, Caenis sp. was common at the sites with lower flow velocity, warmer water and deposited plant residues. In the delta, Heptageniidae family is represented by only one $H$. flava species due to the absence of rocky substrates, high water turbidity and predominance of silty soils. The presence of submerged substrates, such as driftwood, on which it is able to settle, favors the settlement of this species. P. luteus was registered once at the river part near Murzino village, whereas it was very rare in the delta.

Baikal amphipods, Gmelinoides fasciatus (Stebbing, 1899) and Micruropus possolskii Sowinsky, 1915 (Table) were found in abundant at most studied delta sites. Micruropus wohlii platycercus (Dybowsky, 1874) was encountered at the outer side of the Selenga

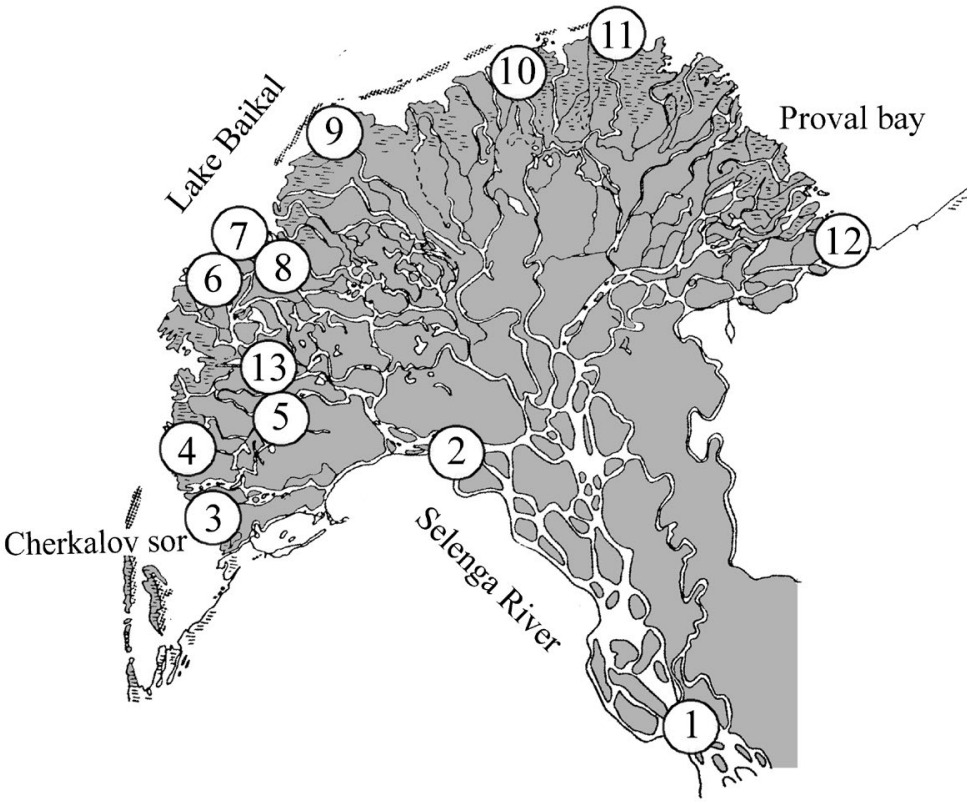

Fig.1. Schematic presentation of zoobenthos sampling sites in the Selenga delta in 2002.

1 - Selenga River near Kabansk village; 2 - Selenga River near Murzino village; 3 - Levoberezhnaya channel (mouth); 4 - Shamanka channel (mouth); 5 - Kharauz channel near Semenovsky Island; 6 - Kharauz channel (mouth); 7 - Galatuy channel (mouth); 8 - Galatuy channel; 9 - Srednyaya channel (mouth); 10 - Kolpinaya channel (mouth); 11 - Severnay channel (mouth); 12 - Lobanovskaya channel (mouth); 13 Lake Zavernyaikha.

avandelta facing Baikal, as well as in Galatuy and Kharauz channels (mouth area). The largest numbers of this species (up to $240 \mathrm{ind} . / \mathrm{m}^{2}$ ) were observed in the region of Bolshaya Prorva in October 2002. No Baikal amphipod species were registered either at the part of the Selenga River near Kabansk settlement where the river did not yet branch into delta channels and was a typical submountain river, or in the vicinity of Murzino settlement (upper delta part).

The abundance of zoobenthos in the upper delta part near Murzino settlement was as high as 7280 ind. $/ \mathrm{m}^{2}$, biomass $-16.24 \mathrm{~g} / \mathrm{m}^{2}$, their average values from May until October being $1975 \pm 1358$ ind./ $\mathrm{m}^{2}$ and $2.90 \pm 2.23 \mathrm{~g} / \mathrm{m}^{2}$. Directly in the channels of the left delta margin these values were significantly higher (Table). Their abundance peak was registered in March with subsequent decrease up to minimal numbers in May (Table), in October, zoobenthos showed relatively high abundances again. In October 2002, average abundance values of zoobenthos varied from 6720 to 17960 ind. $/ \mathrm{m}^{2}$, biomass - from 19.24 to $50.52 \mathrm{~g} /$ $\mathrm{m}^{2}$ (Table), maximal values reached 34320 ind. $/ \mathrm{m}^{2}$ and $73.32 \mathrm{~g} / \mathrm{m}^{2}$ in Kharauz channel. The dominant zoobenthos species, ranked by biomass in channels on the left delta side, were amphipods (65.9\%), bivalves (14.5\%), represented by Pisidium baicalense Dybowski, 1902, and oligochaetes (13.8\%) (Table). Amphipods were dominated by $\mathrm{Gm}$. fasciatus and M. possolskii, oligochaetes by the representatives of the family Tubificidae. 
Table. Quantitative development of zoobenthos in the channels on the left margin of the Selenga delta in 2002.

\begin{tabular}{|c|c|c|c|c|c|c|}
\hline Taxon & March & May & June & July & October & March-October \\
\hline Oligochaeta & $\frac{5893 \pm 2713}{8.51 \pm 4.10}$ & $\frac{1427}{1.12}$ & $\frac{2185 \pm 932}{3.41 \pm 1.69}$ & $\frac{5960 \pm 2996}{1.89 \pm 0.88}$ & $\frac{8485 \pm 3876}{6.25 \pm 3.26}$ & $\frac{4790 \pm 1310}{4.23 \pm 1.38}$ \\
\hline Bivalvia & $\frac{320 \pm 162}{5.31 \pm 3.75}$ & $\frac{27}{0.37}$ & $\frac{435 \pm 228}{1.58 \pm 0.62}$ & $\frac{190 \pm 53}{2.79 \pm 1.19}$ & $\frac{285 \pm 121}{12.18 \pm 6.03}$ & $\frac{251 \pm 68}{4.45 \pm 2.10}$ \\
\hline Amphipoda & $\frac{6453 \pm 1205}{67.37 \pm 16.63}$ & $\frac{1027}{4.69}$ & $\frac{4790 \pm 1840}{4.21 \pm 1.33}$ & $\frac{4530 \pm 3761}{12.19 \pm 10.59}$ & $\frac{1260 \pm 250}{12.38 \pm 2.74}$ & $\frac{3612 \pm 1061}{20.17 \pm 11.93}$ \\
\hline Others & $\frac{226 \pm 207}{1.00 \pm 0.90}$ & $\frac{173}{0.40}$ & $\frac{1321 \pm 840}{2.53 \pm 1.59}$ & $\frac{420 \pm 195}{0.35 \pm 0.11}$ & $\frac{1565 \pm 531}{4.37 \pm 2.42}$ & $\frac{745 \pm 294}{1.74 \pm 0.77}$ \\
\hline Benthos & $\frac{12893 \pm 3794}{82.19 \pm 22.50}$ & $\frac{2653}{6.59}$ & $\frac{8731 \pm 1643}{11.73 \pm 2.69}$ & $\frac{11100 \pm 2922}{17.22 \pm 10.82}$ & $\frac{11595 \pm 3912}{35.18 \pm 7.18}$ & $\frac{9395 \pm 1814}{30.58 \pm 13.77}$ \\
\hline
\end{tabular}

\section{Discussion}

Abundance of Baikalian amphipods and molluscs as well as their penetration into the delta led to the mixed zoobenthos composition represented both widespread and endemic Baikal taxons. Gm. fasciatus and $M$. possolskii abundant in the delta were not able to move against fast river current and overcome upper delta boundary. None of them were registered in zoobenthos of the main river channel on the territory of the Russian Federation (Vershinin, 1964; Bazova and Bazov, 2006). Typical lake forms of amphipods belonging to Baikal fauna - M. wohlii platycercus and Holarctic fauna - Gammarus lacustris Sars, 1863 have a limited distribution in delta (Matafonov and Matafonov, 2008). Their biotopes are clearly delineated in the delta: $M$. wohlii platycercus is confined to clean welldrained sands of the avandelta, G. lacustris to slowflowing streams overloaded with organic matter and the community dominated by Erpobdella octoculata (L., 1758) leech. Substitution of rheophilic mayfly species by amphipods adapted to lotic-lentic environments indicates a buffer function of the delta and ecotonisation of its communities.

Zoobenthos inhabiting channels on the left Selenga delta margin is characterized by high quantitative parameters compared to that from the main river channel (Bazova, 2004). Decrease in the zoobenthos abundance during summer may be a result of specific seasonal dynamics of the dominating zoobenthos populations. For example, analysis of the demographic structure of amphipod populations showed decrease of average weight of crustaceans in spring-summer period caused by juvenile hatching and loss of the parental population (Fig. 1). Another reason of that was, probably, spring floodings which are one of the main factors decline of zoobenthos abundance in the main river channel in spring and summer (Vershinin, 1964).

We assume that factors determining changes in the zoobenthos from the delta are as follows: silting of bootom sediments (Vershinin, 1964) and transformation of sediments chemical composition (Khazheeva et al., 2005), decrease in the concentration of water pollutants (Sorokovikova et al., 2000), increase of the abundance and biomass of phytoplankton as well as heterotrophic microorganisms, and involvement of the bulk of biogenic elements of Selenga water into the biological turnover in the delta (Sorokovikova et al., 2005). Apparently, these factors in total determine changing the rheophilic zoobenthos complex from the upper and middle river streams into the lacustrineriverine complex of the delta channels even before Selenga enters Lake Baikal. It allows us to consider the delta as an ecological barrier, on the one hand, preventing introduction of Baikal fauna into middle and upper streams of the Selenga River, and on the other hand, penetration of widespread rheophilic fauna into Lake Baikal. In the authors' opinion, decrease of the stream velocity in the delta (Sinyukovich et al., 2004) and opposite direction of the flow, requiring significant efforts to overcome it, are main factors in the formation of a mixed composition of zoobenthos in the delta.

Apparently, the trophic basis of the delta zoobenthos, as has been shown previously for Selenga shoal of Lake Baikal (Bekman, 1971), is allochthonous organic matter, abundantly represented by the remains of terrestrial vegetation in the delta sediments and in the gut of benthic animals. Thus, allochtonic matter determines the trophic relationships of Baikal fauna with that of the Selenga drainage basin and contributes to specialization and functional role of zoobenthos of the delta channels in utilizing its different fractions: suspended (bivalves), sedimented (amphipods) and buried (oligochaetes). Abundant of amphipods may attest to supply of low-mineralized organic matter (Cherepanov, 1978) and significant role of zoobenthos and Baikal endemics in particular in its transformations in bottom biotopes.

The results obtained during studies on the channels of the left side of the delta in 2002 are comply with the previous data (Vershinin, 1964) on increase numbers of zoobenthos as it reaches the lower part of the Selenga River, and change of litho-rheophilic zoobenthic communites by psammo-pelophilous lake-river communites, as well as with the reports on mixing of river and lake faunas in the delta channels, and oligochaete and Baikal amphipod abundance in 
the delta channels (Syroezhkina, 1973). Taking into account scarcity of multi-year observations on the state of zoobenthos in the delta, the results provide evidence on preservation of principal characteristics of the delta ecosystem as an ecotonic zone at the time of investigations in 2002.

\section{Conclusions}

Despite the limited amount of material and the approximate results of the study we believe that the results of this work will be useful in understanding the long-term dynamics of zoobenthos and delta ecosystem, as well as in designing optimal a network of monitoring stations and research approaches. In our view, further studies of zoobenthos in the Selenga delta from structural and functional approach will enable us to understand physical, energetic and informative relationships of a unique biota of Lake Baikal and the catchment area of the Selenga River.

\section{Acknowledgements}

This work was supported by SB RAS Projects № 90 and the Program for Basic Research of the Siberian Branch of the Russian Academy of Sciences, project no. FUFR-2021-0006.

\section{Conflict of interests}

The authors declare no conflict of interests.

\section{References}

Alimov A.F. 2000. Elementy teorii funktsionirovaniya vodnykh ekosistem [Elements of aquatic ecosystem function theory]. St. Petersburg: Nauka. (in Russian)

Bazova N.V. 2004. Spatio-temporal distribution of zoobenthos in the Selenga River and Lake Gusinoe. Cand. Sc. Dissertation, Buryat State University, Russia. (in Russian)

Bazova N.V., Bazov A.V. 2006. Zoobenthos in the Selenga river (Lake Baikal basin) within territory of Russia: spatial distribution during under the ice period. Biologiya vnutrennikh vod [Biology of Inland Waters] 3: 48-56. (in Russian)

Bekman M.Yu. 1971. Quantitative characteristics of zoobenthos. In: Galaziy G.I. (Ed.), Limnologiya pridel'tovykh prostranstv Baykala [Limnology of the near-delta areas. Selenga region]. Leningrad, pp. 114-126. (in Russian)

Cherepanov V.V. 1978. Ecological structure and productivity of bottom population. In: Galaziy G.I., Votintsev K.K. (Eds.), Problemy Baykala [Problems of Baikal]. Novosibirsk, pp. 199-216. (in Russian)

Ecosystems of Selenga basin. 2005. In: Vostokova E.A., Gunin P.D. (Eds.). Moscow: Nauka. (in Russian)

Khazheeva Z.I., Urbazaeva S.D., Tulokhonov A.K. et al. 2005. Heavy metals in the water and bottom sediments of the Selenga River delta. Geokhimiya [Geochemistry] 43(1): 105-111. (in Russian)

Matafonov P.V. 2014. Features of the structure and functioning in the ecosystem of the Selenga River delta. Uspekhi Sovremennogo Yestestvoznaniya [Advances in Current Natural Sciences] 12: 182. (in Russian)

Matafonov D.V., Matafonov P.V. 2008. Macrozoobenthos. In: Tulokhonov A.K., Plyusnin A.M. (Eds.), Del'ta reki Selengi - yestestvennyy biofil'tr i indikator sostoyaniya ozera Baykal [The Selenga river delta - natural biofilter and indicator of the condition lake Baikal]. Novosibirsk, pp. 192-196. (in Russian)

Matafonov D.V., Bazova N.V. 2014. Decline of Gammarus lacustris Sars (Crustacea: Amphipoda) population in the delta of the Selenga River. Biology Bulletin 41(2): 168-175. DOI: 10.1134/S1062359014020071

Matafonov P.V., Itigilova M.Ts., Tashlykova N.A. 2018. Elements of functioning and long-term dynamics of the aquatic ecosystem of Selenga river delta. In: International Conference «Freshwater Ecosystems - Key Problems», pp. 234.

Rozhkova N.A., Sinyukovich N.V., Timoshkin O.A. et al. 2016. Modern state of the biota of the Selenga river delta (Lake Baikal basin) under conditions of unstable hydrological regime. Report II. Macrozoobenthos. Gidrobiologicheskiy Zhurnal [Hydrobiological Journal] 52 (1): 56-68. (In Russian)

Sinyukovich V.N., Zharikova N.G., Zharikov V.D. 2004. Selenga River runoff in its delta. Geografiya i Prirodnyye Resursy [Geography and Natural Resources] 25(3): 64-69. (in Russian)

Sorokina A.A. 1975. Feeding and trophic relationships of young fish in Selenga region of Baikal. Cand. Sc. Dissertation, Irkutsk State University named after A.A. Zhdanova, Russia. (in Russian)

Sorokovikova L.M., Sinyukovich V.N., Golobokova L.P. et al. 2000. Formation of ion runoff of Selenga in today's environment. Vodnyye Resursy [Water Resources] 27(5): 560-565. (in Russian)

Sorokovikova L.M., Tulokhonov A.K., Sinyukovich V.N. et al. 2005. Quality of water in the Selenga River delta. Geografiya i Prirodnyye Resursy [Geography and Natural Resources] 26(1): 73-80. (in Russian)

Syroezhkina N.V. 1973. Benthic population and biological discharge of the Selenga River. In: Galaziy G.I. (Ed.), Krugovorot veshchestva $\mathrm{i}$ energii $\mathrm{v}$ ozerakh $\mathrm{i}$ vodokhranilishchakh. Tom 2. [Turnover of matter and energy in water bodies and reservoirs. V.2]. Listvennichnoe na Baikale, pp. 15-16. (in Russian)

The Selenga river delta - natural biofilter and indicator of the condition lake Baikal. 2008. In: Tulokhonov A.K., Plyusnin A.M. (Eds.). Novosibirsk: SB RAS Publ. (in Russian)

Tulokhonov A.K. 2008. Methodology of research. In: Tulokhonov A.K., Plyusnin A.M. (Eds.), Del'ta reki Selengi yestestvennyy biofil'tr i indikator sostoyaniya ozera Baykal [The Selenga river delta - natural biofilter and indicator of the condition lake Baikal]. Novosibirsk, pp. 9-13. (in Russian)

Vershinin N.V. 1964. Benthic fauna of the Selenga River and its importance for fisheries. Trudy Sibirskogo otdeleniya GosNIORKH [Proceedings of Siberian Branch of GosNIIORKH] 8: 219-249. (in Russian) 